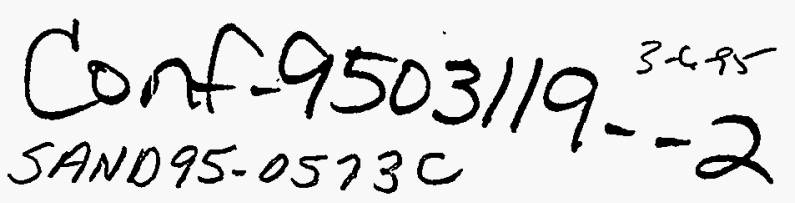

\section{Intermetallic Compound Layer Growth Kinetics in Non-Lead Bearing Solders ${ }^{1}$}

\author{
P.T. Vianco \\ A.C. Kilgo \\ R. Grant \\ Sandia National Laboratories \\ Albuquerque, NM
}

\begin{abstract}
The introduction of alternative, non-lead bearing solders into electronic assemblies requires a thorough investigation of product manufacturability and reliability. Both of these attributes can be impacted by the excessive growth of intermetallic compound (IMC) layers at the solder/substrate interface. An extensive study has documented the stoichiometry and solid state growth kinetics of IMC layers formed between copper and the lead-free solders: $96.5 \mathrm{Sn}-3.5 \mathrm{Ag}$ (wt.\%), $95 \mathrm{Sn}-5 \mathrm{Sb}, 100 \mathrm{Sn}$, and $58 \mathrm{Bi}-42 \mathrm{Sn}$. Aging temperatures were $70-205^{\circ} \mathrm{C}$ for the $\mathrm{Sn}$-based solders and $55-120^{\circ} \mathrm{C}$ for the Bi-rich solder. Time periods were 1-400 days for all of the alloys. The $\mathrm{Sn} / \mathrm{Cu}$, $\mathrm{Sn}-\mathrm{Ag} / \mathrm{Cu}$, and $\mathrm{Sn}-\mathrm{Sb} / \mathrm{Cu} \mathrm{IMC}$ layers exhibited sub-layers of $\mathrm{Cu}_{6} \mathrm{Sn}_{5}$ and $\mathrm{Cu}_{3} \mathrm{Sn}$; the latter composition was present only following prolonged aging times or higher temperatures. The total layer growth exhibited a time exponent of $n=0.5$ at low temperatures and a value of $n=0.42$ at higher temperatures in each of the solder $/ \mathrm{Cu}$ systems. Similar growth kinetics were observed with the low temperature $58 \mathrm{Bi}-42 \mathrm{Sn}$ solder, however, a considerably more complex sub-layer structure was observed. The kinetic data will be discussed with respect to predicting IMC layer growth based upon solder composition.
\end{abstract}

\section{Introduction}

Soldering provides the primary means for assembling electronic devices, subsystems, and products for both consumer and military applications. Cost-effective

1This work was performed at Sandia National Laboratories, which is supported by the U.S. Dept. of Energy under contract number DE-AC04-94AL95000. 


\section{DISCLAIMER}

This report was prepared as an account of work sponsored by an agency of the United States Government. Neither the United States Government nor any agency thereof, nor any of their employees, make any warranty, express or implied, or assumes any legal liability or responsibility for the accuracy, completeness, or usefulness of any information, apparatus, product, or process disclosed, or represents that its use would not infringe privately owned rights. Reference herein to any specific commercial product, process, or service by trade name, trademark, manufacturer, or otherwise does not necessarily constitute or imply its endorsement, recommendation, or favoring by the United States Government or any agency thereof. The views and opinions of authors expressed herein do not necessarily state or reflect those of the United States Government or any agency thereof. 


\section{DISCLAIMER}

Portions of this document may be illegible in electronic image products. Images are produced from the best available original document. 
manufacturing processes, which are required of companies that wish to compete in the global marketplace, require the minimization of assembly defects that can lead to postfabrication repair and rework or, worse, service failures in the field. The $\mathrm{Sn}-\mathrm{Pb}$ solders, $63 \mathrm{Sn}-37 \mathrm{~Pb}(\mathrm{wt} \%)$ and $60 \mathrm{Sn}-40 \mathrm{~Pb}$, have provided a reliable attachment technology for electronic systems. Also, $\mathrm{Sn}-\mathrm{Pb}$ solders have readily accommodated ongoing device and system miniaturization as well as the demand for low-cost, high volume manufacturing processes.

However, $\mathrm{Pb}$, which is a principle component of electronic-grade solders, poses a hazard to human health as well as to the environment. Restrictions on the use of $\mathrm{Pb}$ in a wide range of manufactured products, either by means of legislation or tax incentives, will cause the electronics community to develop alternative solders for their products. The logistics for replacing such a well established technology as tin-lead soldering with alternative non-lead bearing alloys will require that the following tasks be exercised: (1) development of suitable alloy compositions with desired thermal, mechanical, and physical metallurgy properties; (2) implementation of cost-effective manufacturing processes for electronics assembly; (3) establishment of a reliability database to predict the service lifetime of solder joints, and (4) the growth of an industry-wide infrastructure that will provide support technologies such as fluxing materials as well as alternative, $\mathrm{Pb}$ free circuit board and package lead finishes. Already, considerable effort has been given to these aspects; the reader is referred to citations $[1,2,3,4,5]$ for detailed discussions.

An important aspect of the physical metallurgy of alternative solders is the reaction layer formed at the interface between the solder and the $\mathrm{Cu}$ substrate. This reaction layer is comprised of covalent or "intermetallic" compounds of $\mathrm{Sn}$ and $\mathrm{Cu}$. The intermetallic compound (IMC) layer forms, initially, as a part of the wetting process by the molten solder, however, it can also develop further by solid state diffusion processes after joint solidification. The solid state growth rate increases with temperature and time duration. Shown in Fig. 1a is the IMC layer which develops between $63 \mathrm{Sn}-37 \mathrm{~Pb}$ and $\mathrm{Cu}$ after thermal aging at $170^{\circ} \mathrm{C}$ (solid state) for 402 days. The $\mathrm{Cu}_{3} \mathrm{Sn}$ and $\mathrm{Cu}_{6} \mathrm{Sn}_{5}$ sublayers are identified as the $\varepsilon$ and $\eta^{\prime}$, respectively, from the $\mathrm{Cu}-\mathrm{Sn}$ binary phase diagram in Fig. 1b. An IMC layer indicates that, in fact, a metallurgical bond has formed between the molten solder and the substrate surface.

In electronic applications, the IMC layer impacts largely the manufacturability of solder joints during product assembly. This effect comes about because, in most instances, the package lead or termination as well as the copper land and/or plated through hole on the printed circuit board have been deposited with a $100 \mathrm{Sn}$ or $63 \mathrm{Sn}-37 \mathrm{~Pb}$ coating prior to assembly. By establishing a layer of $\mathrm{Sn}$ or $\mathrm{Sn}-\mathrm{Pb}$ solder on the base 
metal surfaces before the attachment process, wettability of the surfaces has already been assured. In the case of hot solder dipped coatings, poor wetting by either the individual components (i.e., package I/O or circuit board feature) or the circuit board features can be remedied before assembly. This is a more cost effective approach than having to inspect for, and rework, defective joints on the final product.

However, long term storage of electronic components or their exposure to elevated temperatures during such life testing as "burn-in" or thermal cycling accelerate the solid state growth of the IMC layer between the base metal and the $\mathrm{Sn}$ or solder coating. Moreover, such coatings are intentionally made very thin in order to prevent excessive solder from accumulating in the joint at the time of assembly, thereby reducing the likelihood of damage to, and/or misalignment of, the very small leads on fine pitch technology packages. On the other hand, a consequence of limited coating thicknesses is that under elevated temperature conditions, the IMC layer can potentially grow to an extent so as to consume the entire $\mathrm{Sn}$ or $\mathrm{Sn}-\mathrm{Pb}$ coating. The IMC layer is then exposed to the atmosphere whereby it readily oxidizes and becomes non-solderable, even under the strongest fluxes allowable in electronics manufacturing. The consequence is defective solder joints on the product. Therefore, it is necessary to establish the growth kinetics of IMC layers formed between $\mathrm{Cu}$ and alternative, non-lead bearing solders so as to be able to predict device (and circuit board ) solderability following long term storage or life testing procedures.

The formation and thickness of the IMC layer can also affect the reliability of the solder joints; albeit, this factor is of lesser pertinence to electronics applications except for unusual applications. By the covalent nature of the bonds, the $\mathrm{Cu}_{3} \mathrm{Sn}$ and $\mathrm{Cu}_{6} \mathrm{Sn}_{5}$ sub-layers have very limited ductility. The brittle nature of the IMC will affect joint strength under impact load conditions (i.e., forces applied at a high rate). Although fracture of the IMC layer has the potential to be catastrophic from the sense of a loss of mechanical integrity as well as electrical continuity, such a failure mode is not traditionally observed in the service life of most $\mathrm{Sn}-\mathrm{Pb}$ solder-based electronic products. The mechanical loads experienced by a solder joint are typically limited to residual stresses generated by the thermal expansion mismatch between the circuit board laminate and the device package. Such loads develop as a consequence of assembly processes or thermal cycling conditions, causing time dependent deformation to take place within the solder. The IMC layer typically does not have an explicit role in this mode of deformation.

This study will outline the growth kinetics of the IMC layers which form between $\mathrm{Pb}$-free alloys: $100 \mathrm{Sn}, 96.5 \mathrm{Sn}-3.5 \mathrm{Ag}, 95 \mathrm{Sn}-5 \mathrm{Sb}$, and $58 \mathrm{Bi}-42 \mathrm{Sn}$ with $\mathrm{Cu}$. A brief 
description of the IMC structure will be presented for each bi-metal couple along with the kinetic data of IMC layer thickness versus time. Trends will be sought that correlate the solder alloy physical metallurgy, solder thermal properties, and aging temperature with IMC layer thickness.

\section{Experimental Procedures}

The substrates used in this investigation were oxygen-free, high conductivity $\mathrm{Cu}$ tabs measuring $0.635 \times 0.635 \times 0.159 \mathrm{~cm}$. The composition of the $\mathrm{Cu}$ was verified by atomic emission spectroscopy to have the following contaminants and maximum content levels: $40 \mathrm{ppm} \mathrm{Ag}, 50 \mathrm{ppm} \mathrm{Al}, 10 \mathrm{ppm} \mathrm{Mg}, 30 \mathrm{ppm} \mathrm{Mn}$, and $10 \mathrm{ppm} \mathrm{Si}$ (with an error of a factor of two). The surface on which the thickness values were taken, was optically polished.

The $\mathrm{Cu}$ substrates were hot solder coated by dipping each specimen into a bath of the molten metal or alloy. The solders, their liquidus $\left(\mathrm{T}_{1}\right)$ and solidus temperatures $\left(\mathrm{T}_{\mathrm{S}}\right)$, as well as their bath or working temperatures $\left(\mathrm{T}_{\mathrm{w}}\right)$ were: $100 \mathrm{Sn}\left(\mathrm{T}_{\mathrm{l}}=\mathrm{T}_{\mathrm{s}}=232^{\circ} \mathrm{C}\right.$, $\left.\mathrm{T}_{\mathrm{W}}=270^{\circ} \mathrm{C}\right) ; 96.5 \mathrm{Sn}-3.5 \mathrm{Ag}\left(\mathrm{T}_{1}=\mathrm{T}_{\mathrm{S}}=221^{\circ} \mathrm{C}, \mathrm{T}_{\mathrm{W}}=260^{\circ} \mathrm{C}\right) ; 95 \mathrm{Sn}-5 \mathrm{Sb}\left(\mathrm{T}_{1}=232, \mathrm{~T}_{\mathrm{s}}=240^{\circ} \mathrm{C}\right.$, $\left.\mathrm{T}_{\mathrm{W}}=280^{\circ} \mathrm{C}\right)$, or $58 \mathrm{Bi}-42 \mathrm{Sn}\left(\mathrm{T}_{1}=\mathrm{T}_{\mathrm{S}}=139^{\circ} \mathrm{C}, \mathrm{T}_{\mathrm{W}}=190^{\circ} \mathrm{C}\right)$ solder. The details of the coating procedure can be found in Reference 6 .

Thermal aging of the solder-coated test samples was performed in air furnaces with a temperature stability of $\pm 0.5^{\circ} \mathrm{C}$. The annealing temperatures were $70,100,135$, 170 , and $205^{\circ} \mathrm{C}$ for the $100 \mathrm{Sn}, 96.5 \mathrm{Sn}-3.5 \mathrm{Ag}$, and $95 \mathrm{Sn}-5 \mathrm{Sb}$ solders, and $55,70,85,100$, and $120^{\circ} \mathrm{C}$ for the $58 \mathrm{Bi}-42 \mathrm{Sn}$ alloy.. The time periods were 1 to 400 days with a tracking error of $\pm 30 \mathrm{~min}$. Upon completion of the heat treatments, the specimens were cross sectioned and prepared for metallographic analysis. The composition of the intermetallic layers were determined by electron microprobe analysis (EMPA). Measurement of the intermetallic compound layer thickness was performed by quantitative image analysis. Forty measurements were made per sample. A minimum thickness resolved by this technique was $0.5 \mathrm{~mm}$. The data were represented by a mean and \pm one standard deviation.

\section{Results}

A brief description of the IMC layer structure and growth kinetics is outlined below for each of the diffusion couples.

$100 \mathrm{Sn} / \mathrm{Cu}$. An optical micrograph of the IMC layer formed at the $100 \mathrm{Sn} / \mathrm{Cu}$ interface is shown in Fig. 2. The IMC layer was comprised of the $\mathrm{Cu}_{3} \mathrm{Sn}$ and $\mathrm{Cu}_{6} \mathrm{Sn}_{5}$ sub-layers stoichiometries. The total layer thickness as a function of the square root of 
time is shown by the filled symbols in Fig. 3 (thickness values from aging at $205^{\circ} \mathrm{C}$ were not included in this graph). These $100 \mathrm{Sn} / \mathrm{Cu}$ data were overlaid with the results from similar tests on $63 \mathrm{Sn}-37 \mathrm{~Pb}$ (open symbols). The $100 \mathrm{Sn} / \mathrm{Cu}$ total IMC layer grew with parabolic kinetics $(\sqrt{ } \mathrm{t})$ at 70,100 , and $135^{\circ} \mathrm{C}$ and $t^{0.42}$ kinetics at 170 and $205^{\circ} \mathrm{C}$. The apparent activation energy was $66 \mathrm{~kJ} / \mathrm{mol}$. Growth of the $\mathrm{Cu}_{3} \mathrm{Sn}$ sub-layer was parabolic $(\sqrt{t})$ at all temperatures with an apparent activation energy of $43 \mathrm{~kJ} / \mathrm{mol}$.

96.5Sn-3.5Ag/Cu and $95 \mathrm{Sn}-5 \mathrm{Sb} / \mathrm{Cu}$. Optical micrographs of the solder/Cu interface for the $96.5 \mathrm{Sn}-3.5 \mathrm{Ag} / \mathrm{Cu}$ and $95 \mathrm{Sn}-5 \mathrm{Sb} / \mathrm{Cu}$ couples aged at $170^{\circ} \mathrm{C}$ for 150 days are shown in Fig. 4 (the dark shadow at the interface in Fig. 4a is an artifact of the sample preparation/optical microscopy technique and does not represent a crack). The $\mathrm{Cu}_{3} \mathrm{Sn}$ and $\mathrm{Cu}_{6} \mathrm{Sn}_{5}$ sub-layers were observed after aging at temperatures of 170 and $205^{\circ} \mathrm{C}$ for 96.5Sn-3.5Ag solder and 135 (time $>25$ days), 170 , and $205^{\circ} \mathrm{C}$ for $95 \mathrm{Sn}-5 \mathrm{Sb}$ alloy. Both solder/Cu systems exhibited total IMC layer growth kinetics similar to those of $100 \mathrm{Sn} / \mathrm{Cu}$, i.e., $\sqrt{t}_{\mathrm{t}}$ growth at $\mathrm{T} \leq 135^{\circ} \mathrm{C}$ and $t^{0.42}$ kinetics at 170 and $205^{\circ} \mathrm{C}$. The IMC layer thickness as a function of $ل_{t}$ for $96.5 \mathrm{Sn}-3.5 \mathrm{Ag} / \mathrm{Cu}$ and $95 \mathrm{Sn}-5 \mathrm{Sb} / \mathrm{Cu}$ are shown in Figs. $5 \mathrm{a}$ and $5 \mathrm{~b}$, respectively. The $96.5 \mathrm{Sn}-3.5 \mathrm{Sn} / \mathrm{Cu}$ and $95 \mathrm{Sn}-5 \mathrm{Sb} / \mathrm{Cu}$ systems exhibited apparent activation energies (for total layer thickness) that were very similar to those measured in the $100 \mathrm{Sn} / \mathrm{Cu}$ system: $59 \mathrm{~kJ} / \mathrm{mol}$ and $61 \mathrm{~kJ} / \mathrm{mol}$, respectively. Growth of the $\mathrm{Cu}_{3} \mathrm{Sn}$ sub-layer exhibited $\sqrt{t}_{\mathrm{t}}$ kinetics in both cases with identical apparent activation energies of $50 \mathrm{~kJ} / \mathrm{mol}$ which were only slightly higher than that for the $100 \mathrm{Sn} / \mathrm{Cu}$ couple.

$58 \mathrm{Bi}-42 \mathrm{Sn} / \mathrm{Cu}$. A complex IMC layer structure developed in this couple; it is exemplified by the optical micrograph in Fig. 6a and accompanying electron microprobe trace in Fig. $6 \mathrm{~b}$ for the sample aged at $120^{\circ} \mathrm{C}$ for 400 days. Generally, the total layer was comprised of one or more $\mathrm{Cu}_{6} \mathrm{Sn}_{5}$ sub-layers separated by $\mathrm{Cu}-\mathrm{Sn}$-Bi sub-layers of varying $\mathrm{Cu}, \mathrm{Sn}$, and $\mathrm{Bi}$ contents. The source of $\mathrm{Bi}$ in the $\mathrm{Cu}-\mathrm{Sn}$-Bi sub-layer(s) was from that which was rejected by the $\mathrm{Sn}$-rich phase (containing $5 \mathrm{wt} \% \mathrm{Bi}$ in solid solution), the $\mathrm{Sn}$ of which formed the $\mathrm{Cu}_{6} \mathrm{Sn}_{5}$ sub-layers. Unlike the $\mathrm{Cu}_{3} \mathrm{Sn}$ and $\mathrm{Cu}_{6} \mathrm{Sn}_{5}$ sub-layers which developed in the $\mathrm{Sn}, \mathrm{Sn}-\mathrm{Ag}$, and $\mathrm{Sn}-\mathrm{Sb}$ solders, the IMC layer formed in the 58Bi$42 \mathrm{Sn} / \mathrm{Cu}$ couple was prone to cracking. Such cracks were observed to have propagated typically between a $\mathrm{Cu}_{6} \mathrm{Sn}_{5}$ sub-layer and a $\mathrm{Cu}-\mathrm{Sn}$-Bi sub-layer. Only the total layer thickness was measured as a function of aging time; those data appear in Fig. 7. The apparent activation energy for total layer growth was very similar to that of the Sn-rich solders, $55 \mathrm{~kJ} / \mathrm{mol}$.

\section{Discussion}


The growth kinetics of the IMC layers were examined with reference to the solder compositions and their melting properties. A fundamental point that is raised with regards to IMC layer growth is whether the growth behavior responds to the environmental (aging) temperature or to the homologous temperature of the particular solder alloy. The homologous temperature is a ratio of the aging temperature to the liquidus temperature expressed in degrees Kelvin (i.e., $T / T_{1}$, with $T$ and $T_{1}$ in ${ }^{\circ} \mathrm{K}$ ). The 100Sn, $96.5 \mathrm{Sn}-3.5 \mathrm{Ag}$, and $95 \mathrm{Sn}-5 \mathrm{Sb}$ solders, as well as the $63 \mathrm{Sn}-37 \mathrm{~Pb}$ (baseline) solder, had similar IMC layer thicknesses after long term aging. For example, at an aging temperature of $170^{\circ} \mathrm{C}$ and a time period of 200 days, the total IMC layer thicknesses for the $100 \mathrm{Sn} / \mathrm{Cu}, 96.5 \mathrm{Sn}-3.5 \mathrm{Ag} / \mathrm{Cu}, 95 \mathrm{Sn}-5 \mathrm{Sb} / \mathrm{Cu}$, and $63 \mathrm{Sn}-37 \mathrm{~Pb} / \mathrm{Cu}$ systems were: 19.9 , $17.8,20.6$, and $21.0 \mu \mathrm{m}$, respectively. This observation suggests that the growth kinetics were largely dependent upon the aging or test temperature rather than upon the homologous temperature (i.e., the composition) of the particular alloy. In addition, similar kinetic parameters of time exponent and apparent activation energy support the observation of little or no composition dependence by the growth process(es). It is worthwhile to point out that, indeed, that the solders represented several different physical metallurgies: $\mathrm{Sb}$ as a solid solution element (95Sn-5Sb): $\mathrm{Ag}$ as $\mathrm{Ag}_{3} \mathrm{Sn}$ intermetallic second phase particles (96.5Sn-3.5Ag); or $\mathrm{Pb}$ as an insoluble second phase (63Sn-37Pb).

Next, a comparison was made of the IMC layer thickness values of the $100 \mathrm{Sn} / \mathrm{Cu}$, $63 \mathrm{Sn}-37 \mathrm{~Pb} / \mathrm{Cu}$, and $58 \mathrm{Bi}-42 \mathrm{Sn} / \mathrm{Cu}$ systems. (The $100 \mathrm{Sn} / \mathrm{Cu}$ data was used to also represent the $96.5 \mathrm{Sn}-3.5 \mathrm{Ag} / \mathrm{Cu}$ and $95 \mathrm{Sn}-5 \mathrm{Sb}$ results due to their similar growth kinetics.) The kinetic parameters of time exponent, " $n$ ", and the apparent activation energy were listed in Table 1 . The time exponents were similar, although, the value of $n$ decreased from 0.5 to 0.42 at higher temperatures for the lead-free solders. The apparent activation energies showed a composition dependence in which the magnitude increased with $\mathrm{Sn}$ content. Also included in the data were the thickness "increase" values (i.e., y-yo where $y$ is the thickness at time, $t$, and $y_{0}$ is the initial thickness at $t=0$ ) and growth rate (dy/dt) as a function of both the aging and the homologous temperatures. Given a constant aging temperature of $100^{\circ} \mathrm{C}$ and time period of 400 days, the thicknesses of the $\mathrm{IMC}$ layers for $\mathrm{Bi}-\mathrm{Sn}, \mathrm{Sn}$, and $\mathrm{Sn}-\mathrm{Pb}$ solders on $\mathrm{Cu}$, were 14.2, 3.3, and $4.5 \mu \mathrm{m}$, respectively. The corresponding growth rates, as determined by the linear best fit

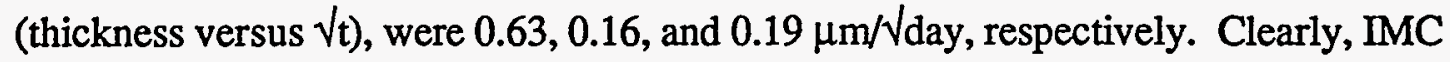
layer growth was not strictly dependent upon the aging (or environment) temperature. Otherwise, similar thickness increases and growth rates should have been observed for each of the alloys. However, the layer thickness did appear to increase in the order of the 
solders with decreasing liquidus temperature. This fact suggested that the aging temperature relative to the liquidus point (i.e., the homologous temperature) had a more significant impact on IMC layer development.

Therefore, the role of homologous temperature was examined as part of the Table 1 analysis. A value of 0.88 was selected for the homologous temperature because it represented test temperatures of 85,170 , and $135^{\circ} \mathrm{C}$ which were accessible to the $58 \mathrm{Bi}$ $42 \mathrm{Sn} / \mathrm{Cu}, 100 \mathrm{Sn} / \mathrm{Cu}$, and $63 \mathrm{Sn}-37 \mathrm{~Pb} / \mathrm{Cu}$ data, respectively. Clearly, the thickness increases were not the same for the given homologous temperature. Upon further examination, the thickness and growth rate data appeared to exhibit an increase with aging temperature (which is the number in parentheses under the thickness value).

The data in Table 1 suggest that IMC layer growth between the 100Sn (which also represents the $\mathrm{Sn}-\mathrm{Ag}$ and $\mathrm{Sn}-\mathrm{Sb}$ solders), 58Bi-42Sn, and $63 \mathrm{Sn}-37 \mathrm{~Pb}$ solders was not predicted strictly by either the aging temperature or by the homologous temperature; rather, $\mathrm{IMC}$ layer development depended upon both of these properties. This point was further supported when all of the temperature data for each of the solders was included in the analysis. The trends exemplified in Table 1 can be explained, based upon the knowledge of probable microstructural processes responsible for IMC layer formation. The IMC layer developed by two processes: (1) the reaction of $\mathrm{Cu}$ and $\mathrm{Sn}$ atoms at the solder and $\mathrm{Cu}$ boundaries, respectively, to form the IMC composition(s) and (2) the diffusion of $\mathrm{Cu}$ and/or $\mathrm{Sn}$ atoms through the layer, to the interfaces to support such reactions. If the diffusion mechanism was dominant, then the IMC layer growth would be largely dependent upon the aging temperature, given the same IMC layer composition, since diffusion within the layer would depend upon the structural of the IMC layer and not the solder field composition. On the other hand, a strong dependence upon the homologous temperature implies that those reactions at the solder interface (which directly involve the solder field) control IMC layer growth.

A mechanistic approach can be used to illustrate the data in Table 1. The 63Sn$37 \mathrm{~Pb} / \mathrm{Cu}$ and $100 \mathrm{Sn} / \mathrm{Cu}$ (which includes the $96.5 \mathrm{Sn}-3.5 \mathrm{Ag} / \mathrm{Cu}$ and $95 \mathrm{Sn}-5 \mathrm{Sb} / \mathrm{Cu}$ ) couples developed the same layer structures. Since the thickness values were similar for a given aging temperature, it was surmised that diffusion processes dominated layer development in these systems. The deviated behavior of the 58Bi-42Sn solder suggested that reaction processes at the IMC layer/solder interface dominated the growth processes of this system. Alternatively, the unusual IMC layer structure generated by the rejected $\mathrm{Bi}$ may have caused diffusion kinetics to be sufficiently different from those of the $100 \mathrm{Sn} / \mathrm{Cu}$ and $63 \mathrm{Sn}-37 \mathrm{~Pb} / \mathrm{Cu}$ systems that the growth behavior of the $58 \mathrm{Bi}-42 \mathrm{Sn} / \mathrm{Cu}$ system did not fit the trend established by the Sn-based alloys. 
In summary, the quantitative data of IMC layer growth suggest that when the traditional $\mathrm{Cu}_{3} \mathrm{Sn}$ and $\mathrm{Cu}_{6} \mathrm{Sn}_{5}$ sub-layers were present, the $\mathrm{IMC}$ growth kinetics were similar and, thus, determined largely by the aging temperature rather than the solder composition-dependent homologous temperature. The controlling microstructural process was solid state diffusion within the IMC layer. The $58 \mathrm{Bi}-42 \mathrm{Sn} / \mathrm{Cu}$ system did not fit this trend. The two likely hypotheses were that (1) an interfacial reaction mechanism dominated the growth process or (2) the presence of the $\mathrm{Cu}-\mathrm{Sn}$-Bi sub-layers in the IMC structure caused changes to the diffusion kinetics in the IMC layer.

From the point-of-view of electronic systems design, a simplified rule based upon aging temperature or the melting properties of the solder could not be developed as a universal approach to predicting IMC layer growth for alternative, $\mathrm{Pb}$-free solders. $\mathrm{A}$ microstructural analysis is necessary in order to identify the IMC layer structure. Should the IMC layer be based upon the development of the $\mathrm{Cu}_{3} \mathrm{Sn}$ and $\mathrm{Cu}_{6} \mathrm{Sn}_{5}$ sub-layers, then its growth kinetics would, in all likelihood, be similar to those of the $100 \mathrm{Sn} / \mathrm{Cu}$ or $63 \mathrm{Sn}$ $37 \mathrm{~Pb} / \mathrm{Cu}$ systems and, hence, be predicted by the particular aging temperature. However, the development of a different IMC layer structure, as was the case with the 58Bi$42 \mathrm{Sn} / \mathrm{Cu}$ system, would require an experimental program to document IMC layer growth.

Finally, this study also demonstrated that the presumption that a reduced IMC layer growth rate would be realized by solders of lower Sn contents, is entirely unfounded. The $58 \mathrm{Bi}-42 \mathrm{Sn}$ solder exhibited the smallest $\mathrm{Sn}$ content; yet, at a given aging temperature, it consistently presented the fastest IMC layer growth rate than was the case of the other three $\mathrm{Pb}$-free solders. Also, the IMC layer in the $58 \mathrm{Bi}-42 \mathrm{Sn} / \mathrm{Cu}$ couple appeared to have a reduced mechanical strength as indicated by the presence of cracks.

\section{Conclusions}

(1) The role of intermetallic compound (IMC) layers in the manufacturability and reliability of solder joints has been documented by the extensive history of $\mathrm{Sn}-\mathrm{Pb}$ solders use in electronic products.

(2) As the electronics engineering community enters the early stages of prototype testing with alternative, $\mathrm{Pb}$-free solders, concerns for the effects of IMC layers will increase in importance.

(3) Isothermal IMC layer growth between $100 \mathrm{Sn}, 96.5 \mathrm{Sn}-3.5 \mathrm{Ag}$, or $965 \mathrm{Sn}-5 \mathrm{Sb}$ solders, and $\mathrm{Cu}$ was documented for time periods of up to 400 days. Parabolic (or nearly so) growth rates as well as the presence of both $\mathrm{Cu}_{3} \mathrm{Sn}$ and $\mathrm{Cu}_{6} \mathrm{Sn}_{5}$ sub-layers in the $\mathrm{Pb}$-free 
solder couples resembled the $63 \mathrm{Sn}-37 \mathrm{~Pb} / \mathrm{Cu}$ system. The ratio of $\mathrm{Cu}_{3} \mathrm{Sn}-\mathrm{to}_{0}-\mathrm{Cu}_{6} \mathrm{Sn}_{5}$, however, differed between the solder composition.

(4) Comparable IMC layer structures between the $96.5 \mathrm{Sn}-3.5 \mathrm{Ag}, 95 \mathrm{Sn}-5 \mathrm{Sb}, 100 \mathrm{Sn}$, and $63 \mathrm{Sn}-37 \mathrm{~Pb}$ solders resulted in similar diffusion-controlled growth kinetics that exhibited a similar aging temperature dependence.

(5) The $58 \mathrm{Bi}-42 \mathrm{Sn} / \mathrm{Cu}$ couples developed complex IMC layer chemistries with traditional $\mathrm{Cu}_{6} \mathrm{Sn}_{5}$ sub-layers separated by $\mathrm{Cu}-\mathrm{Sn}$ - $\mathrm{Bi}$ sub-layers. Although the growth rates were faster than those of the other solders, the kinetic parameters (time exponent and activation energy) were similar.

(6) Differing diffusion rates within the complex IMC layer structure of the or the controlling process being atomistic reactions at the interfaces rather than diffusion, provided the two potential mechanisms for the deviated IMC layer growth behavior of the $58 \mathrm{Bi}-42 \mathrm{Sn} / \mathrm{Cu}$ system. Thickness predictions in such systems, which have nontraditional IMC layer structures, will require experimental measurements in order to obtain the necessary data for the design and process development of electronic products targeted for assembly with $\mathrm{Pb}$-free solders.

\section{Acknowledgments}

The authors wish to thank M.A. Dvorack for his review of the manuscript.

\section{References}

[1] P. Vianco and D. Frear, "Lead in Solders", J. of Metals, 45, (1993), p.14.

[2] P. Vianco and J. Rejent, "Development of a Sn-Ag-Bi Solder for Electronics Assembly Applications", TMS Fall Meeting, Chicago, IL (1994).

[3] P. Vianco and P. Mizik, "Prototyping Lead-Free Solders on Hand-Soldered, ThroughHole Circuit Boards", Proc. 7th SAMPE Mater. and Proc. Elect. Conf., (1994), p.366. [4] P. Vianco and C. May, "Assembly Feasibility Studies of Surface Mount Circuit Boards Manufactured with Lead-Free Solders", Proc. Surf. Mount Inter. (1994) [5] I. Artaki, A. Jackson, U. Ray, and P. Vianco, "Solderability Coatings: Electroless Tin Versus Organic Azoles", Proc. Surface Mount Inter. (1993).

[6] P. Viànco, et al., "Intermetallic Compound Layer Formation Between Copper and Hot-Dipped 100In, 50In-50Sn, 100Sn, and 63Sn-37Pb Coatings", J. Elect. Mater., 23, (1994), p. 583. 


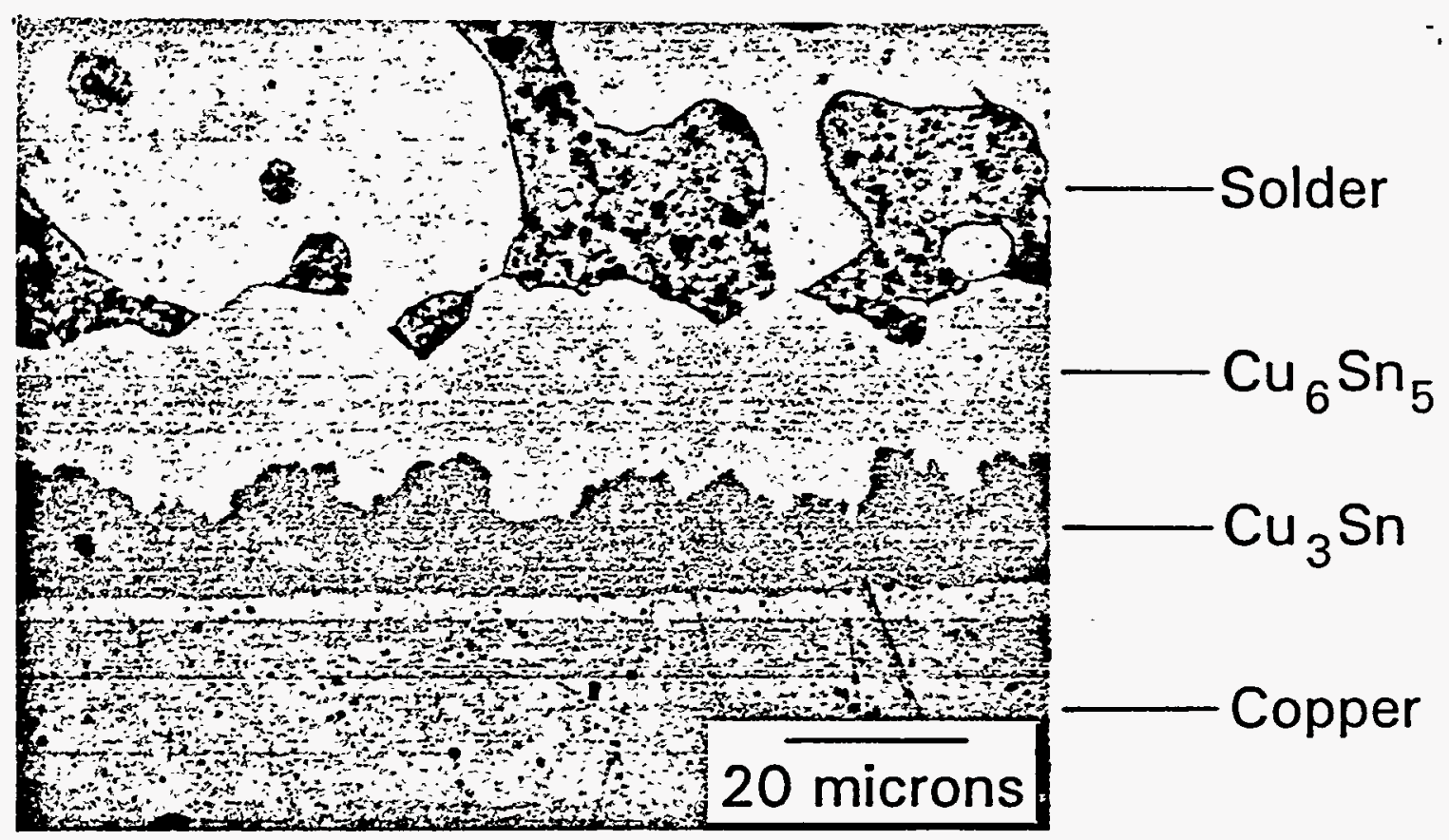

(a)

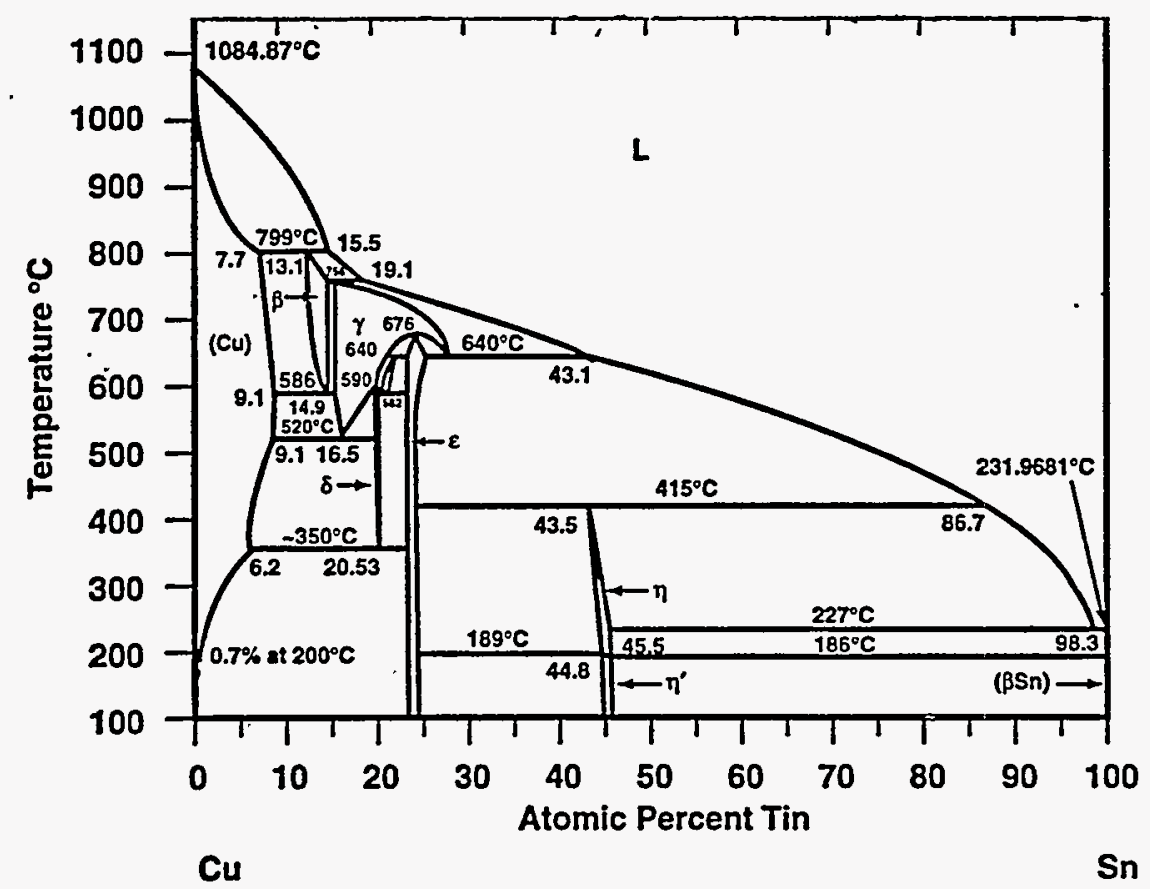

(b)

Fig. 1 (a) Intermetallic compound layer development in the $63 \mathrm{Sn}-37 \mathrm{~Pb} / \mathrm{Cu}$ couple aged at $170^{\circ} \mathrm{C}$ for 402 days. The $\mathrm{Cu}_{3} \mathrm{Sn}$ and $\mathrm{Cu}_{6} \mathrm{Sn}_{5}$ sub-layers were identified as the $\varepsilon$ and $\eta^{\prime}$ phases, respectively, in the Cu-Sn binary phase diagram (b). 


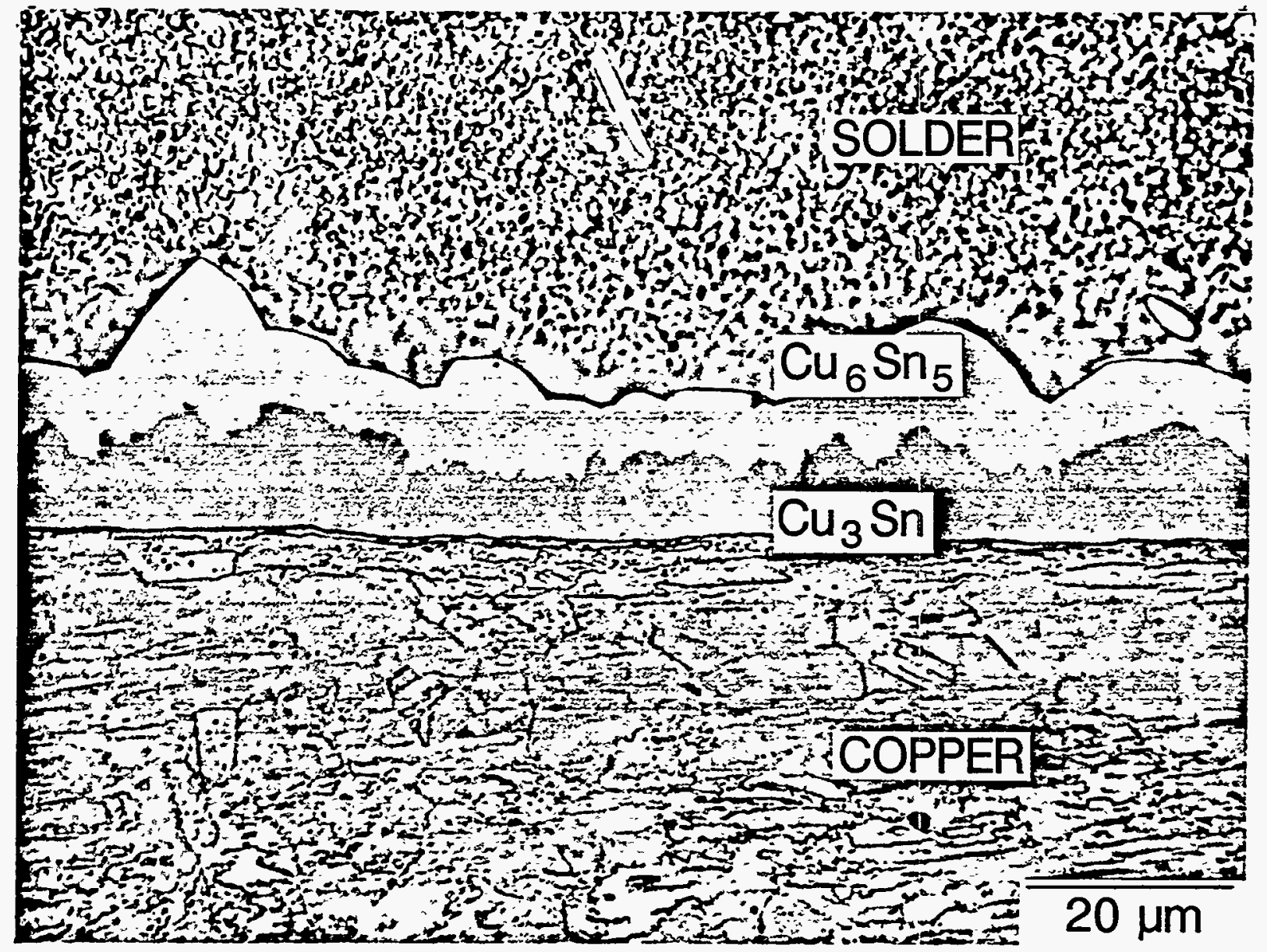

Fig. 2 Optical micrograph of the IMC layer formed at the $100 \mathrm{Sn} / \mathrm{Cu}$ interface by thermal aging at $170^{\circ} \mathrm{C}$ for 200 days. 


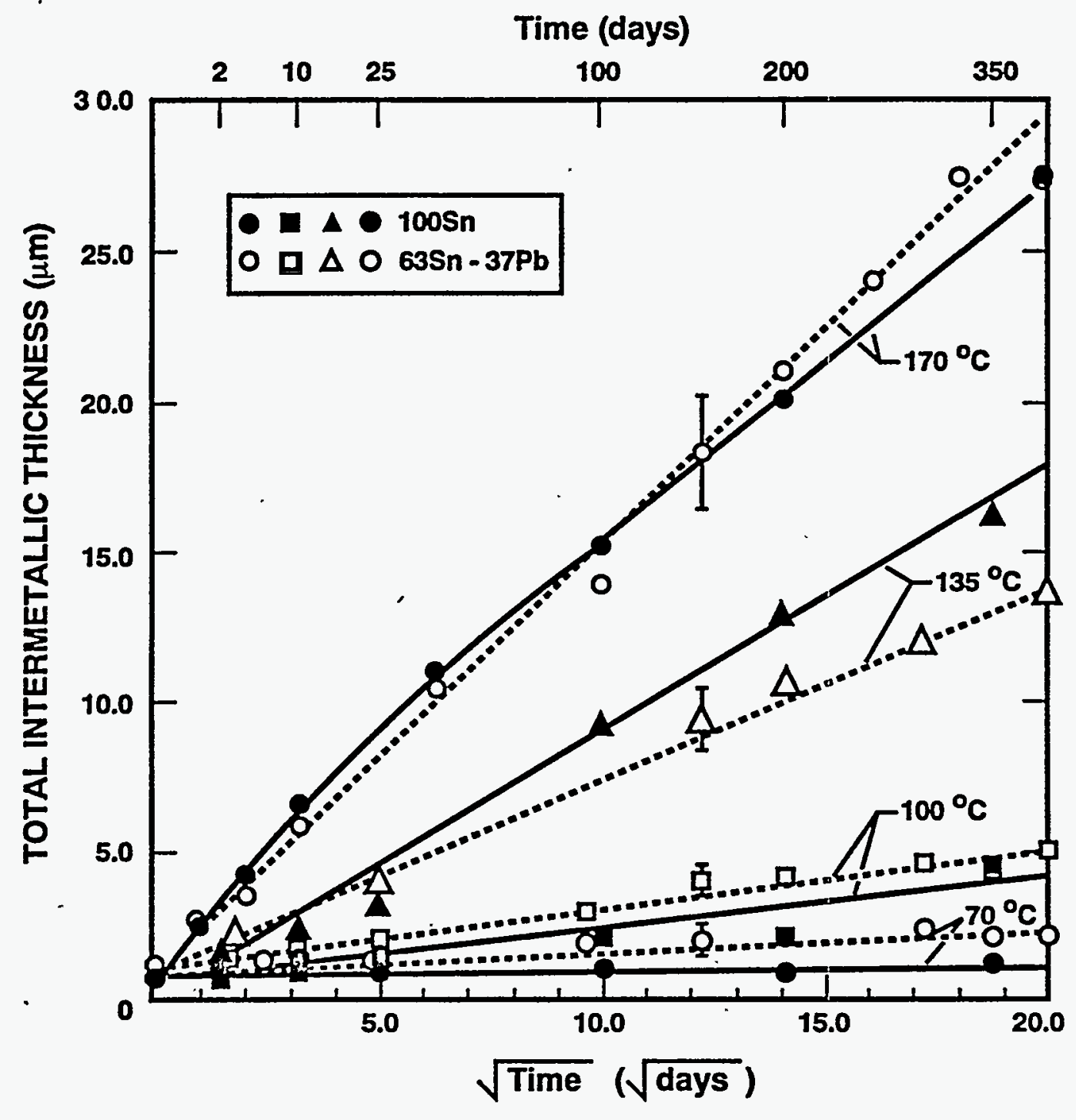

Fig. $3 \mathrm{IMC}$ layer thickness as a function of $\sqrt{t}_{\mathrm{t}}$ for the $100 \mathrm{Sn} / \mathrm{Cu}$ system (filled symbols) and compared with the data from the $63 \mathrm{Sn}-37 \mathrm{~Pb} / \mathrm{Cu}$ couple (open symbols). 

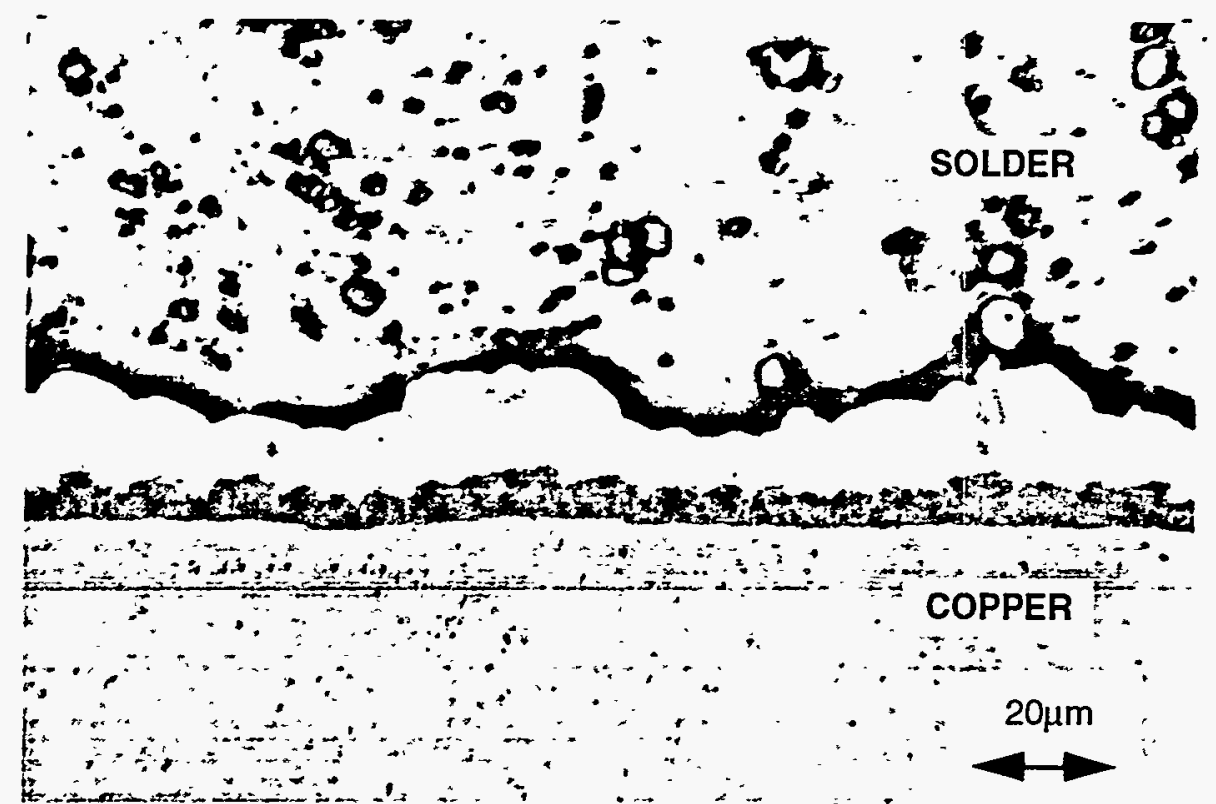

(a)
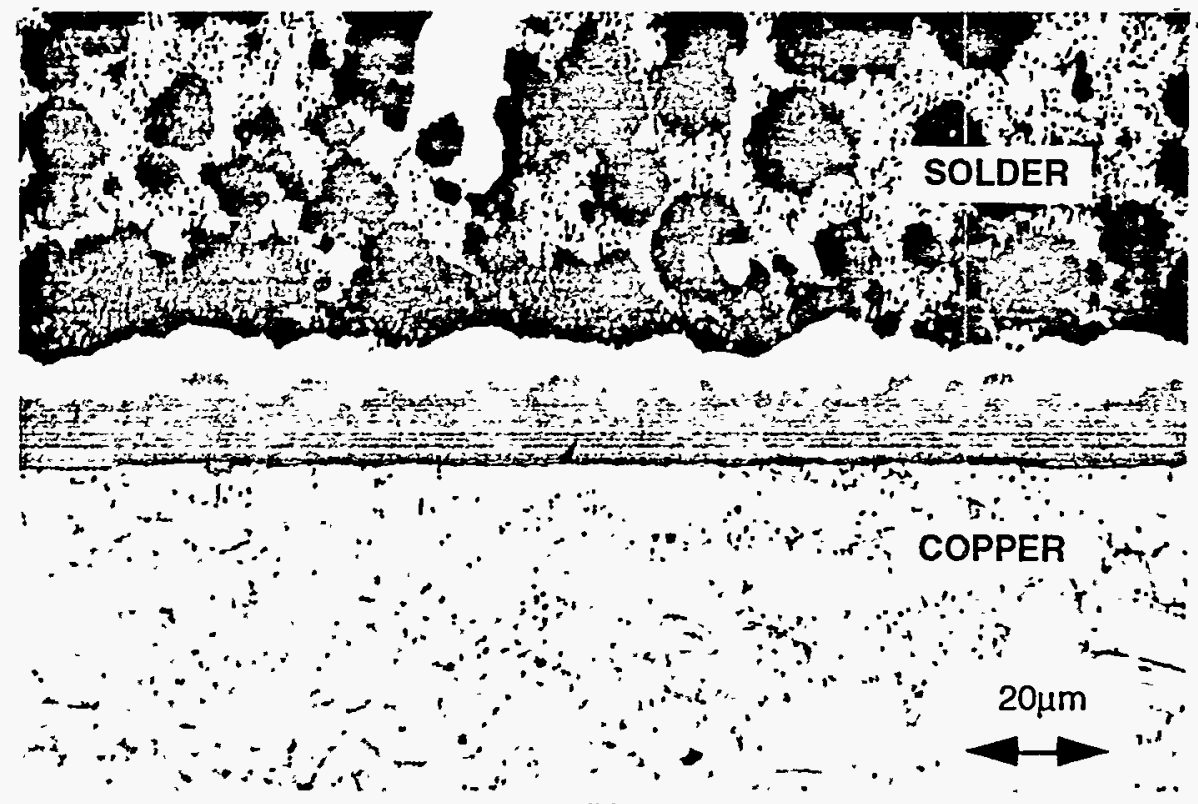

(b)

Fig. 4 Optical micrographs of the (a) $96.5 \mathrm{Sn}-3.5 \mathrm{Ag} / \mathrm{Cu}$ and (b) $95 \mathrm{Sn}-5 \mathrm{Sb} / \mathrm{Cu}$ systems after aging at $170^{\circ} \mathrm{C}$ for 150 days. An artifact of the etching process used to accentuate the IMC layer introduced appeared as a crack (a) and precipitates (b) which did not exist in either case. 


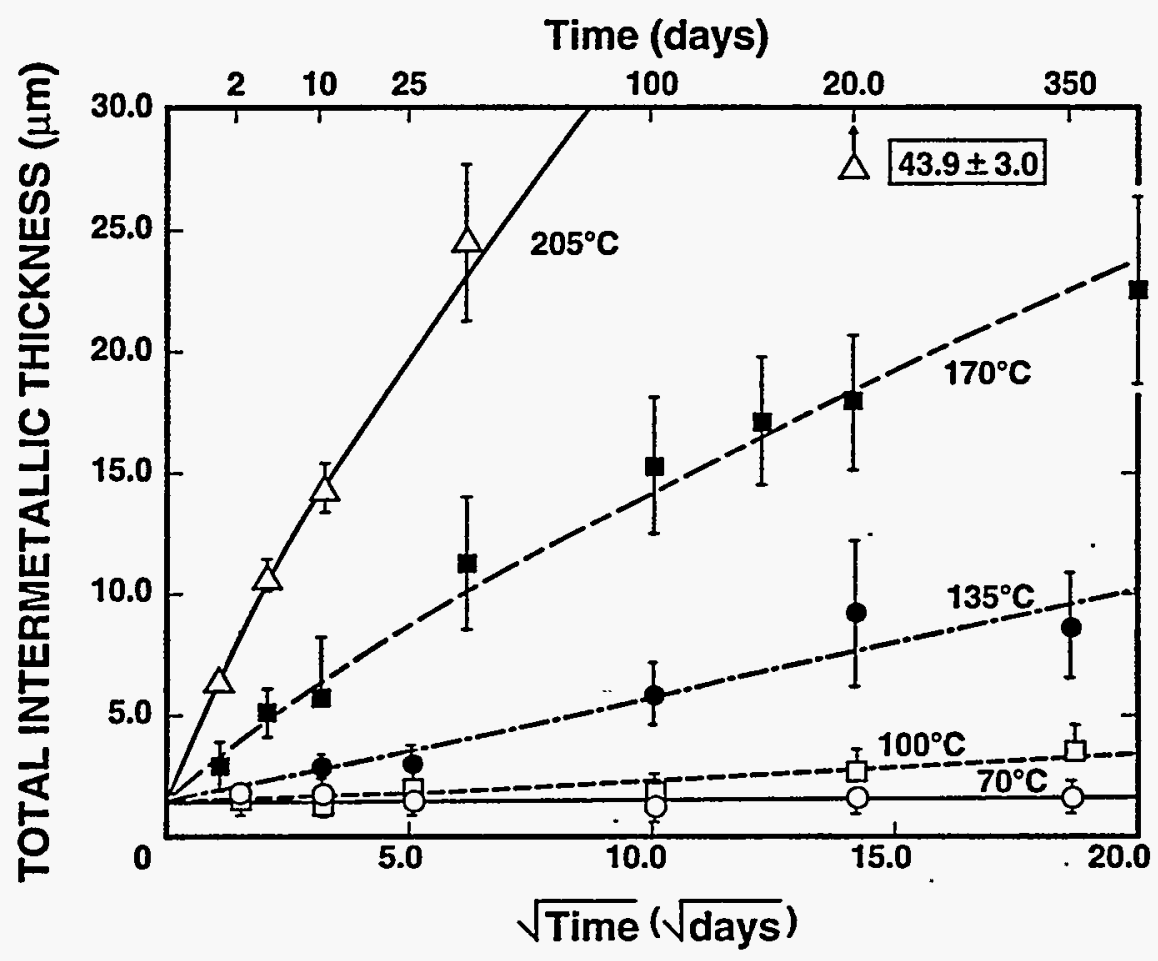

(a)

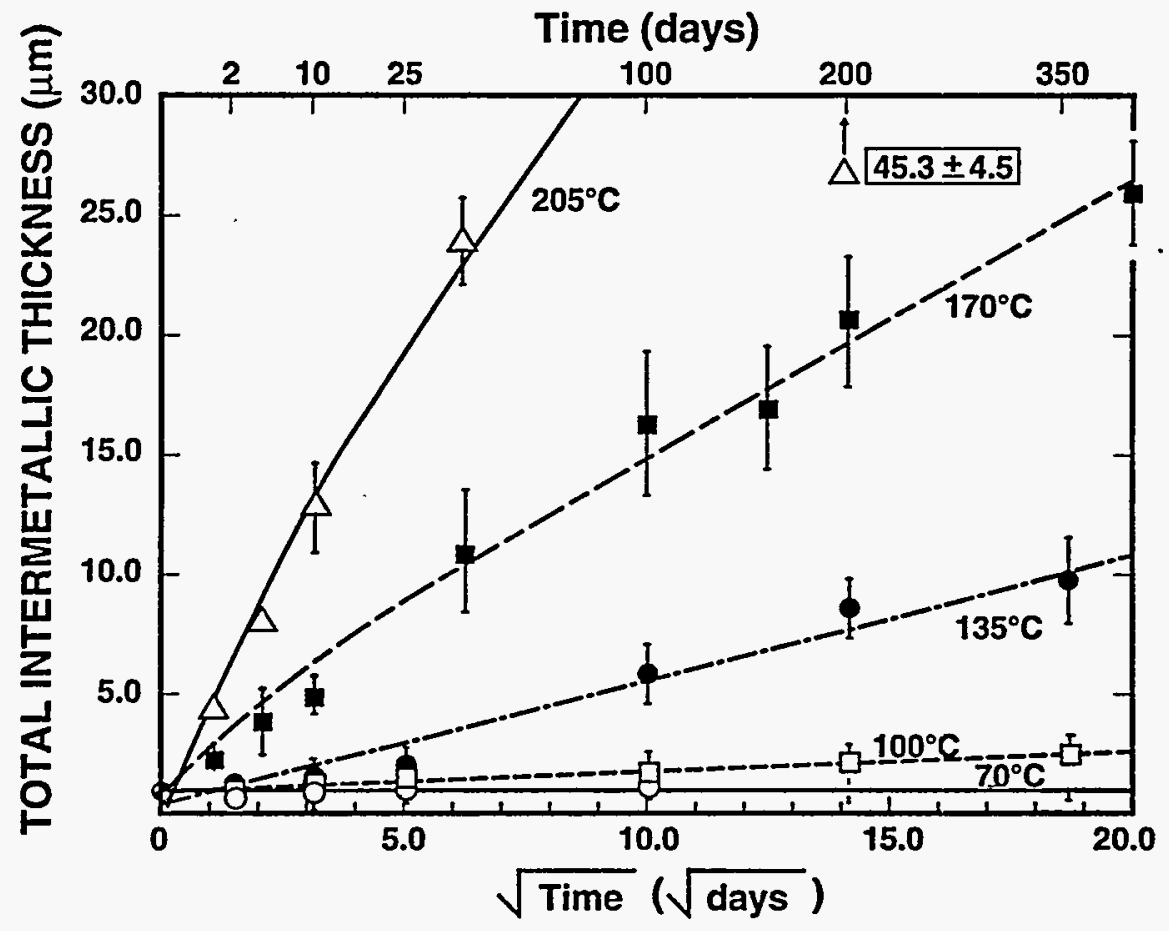

(b)

Fig.5 Growth kinetics of the (a) $96.5 \mathrm{Sn}-3.5 \mathrm{Ag} / \mathrm{Cu}$ and (b) $95 \mathrm{Sn}-5 \mathrm{Sb} / \mathrm{Cu}$ couples as a function of $\sqrt{t}_{\mathrm{t}}$. 

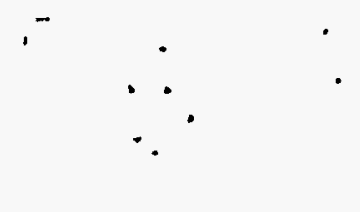

.

-Solder

6

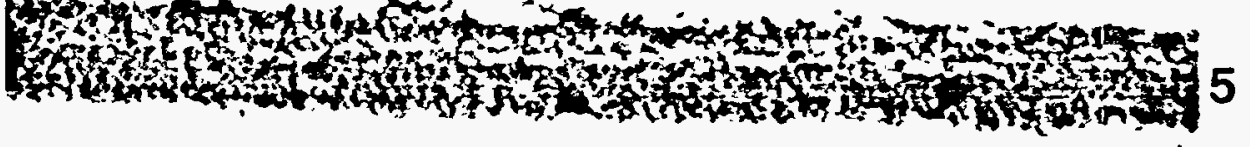

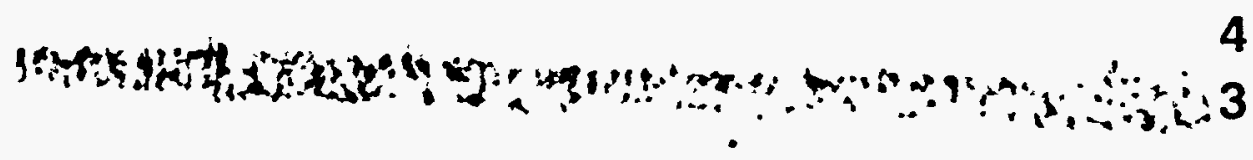

4 IMC

2

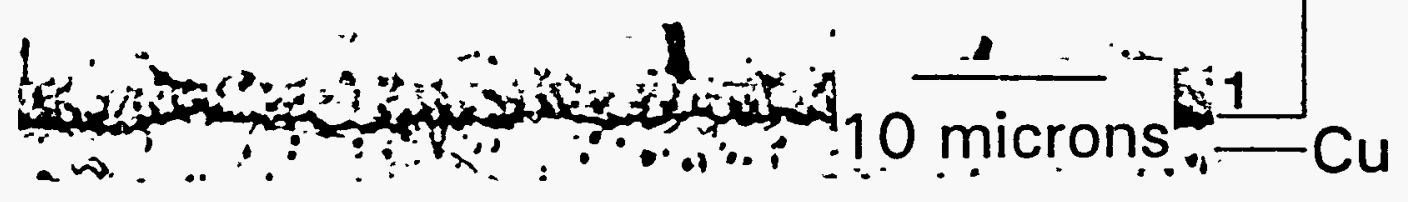

(a)

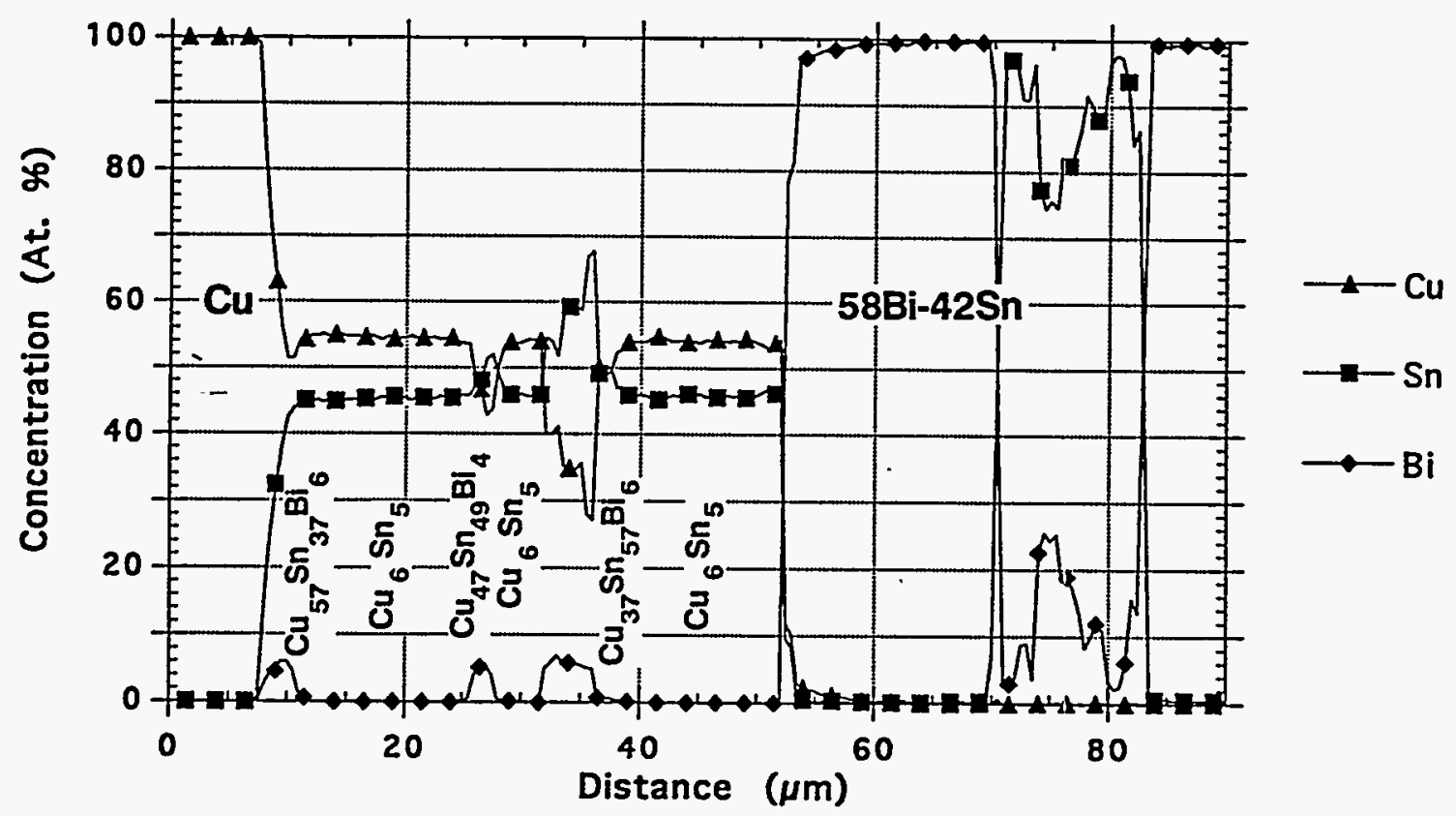

(b)

Fig. 6 (a) IMC layer of the $58 \mathrm{Bi}-42 \mathrm{Sn} / \mathrm{Cu}$ couple after aging at $120^{\circ} \mathrm{C}$ for 400 days. (b) Electron microprobe trace across the IMC layer in (a). 


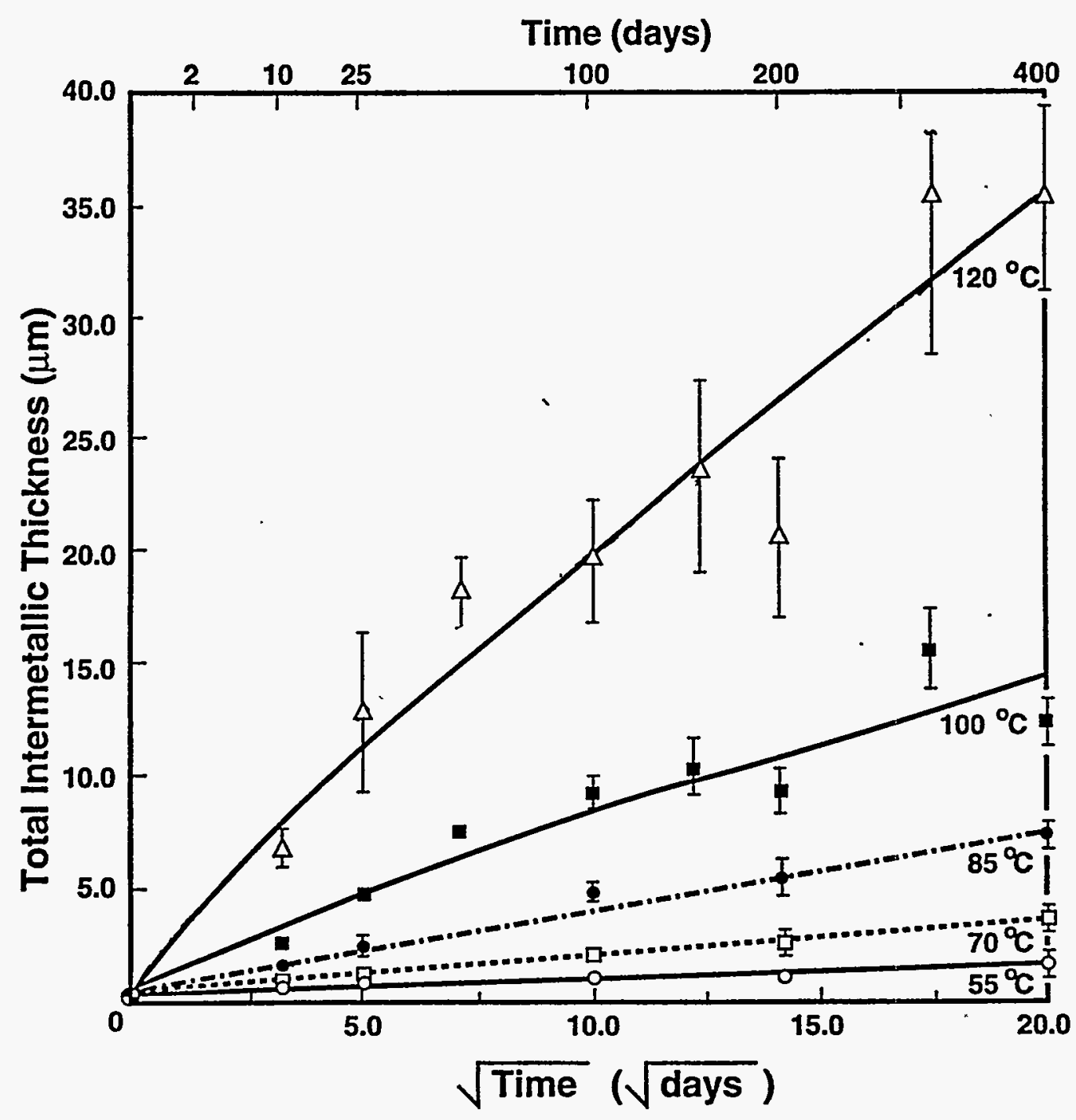

Fig. 7 Growth kinetics of the 58Bi-42Sn/Cu systems as a function of $\sqrt{t}_{\mathrm{t}}$ 


\begin{tabular}{|c|c|c|c|}
\hline Description & $58 \mathrm{Bi}-42 \mathrm{Sn}$ & $100 \mathrm{Sn}$ & $63 \mathrm{Sn}-37 \mathrm{~Pb}$ \\
\hline \multicolumn{4}{|l|}{ Kinetic parameters } \\
\hline - time exponent, $n$ & $0.5 \rightarrow 0.42$ & $0.5 \rightarrow 0.42$ & 0.5 \\
\hline $\begin{array}{l}\text {-activation energy } \\
(\mathrm{kJ} / \mathrm{mol})\end{array}$ & 55 & 66 & 45 \\
\hline \multicolumn{4}{|l|}{ Absolute temp. $100 \mathrm{C}$} \\
\hline $\begin{array}{l}\text { othick. increase } \\
100 \mathrm{C}, 400 \text { days } \\
\text { (microns) }\end{array}$ & 14.2 & 3.3 & 4.5 \\
\hline $\begin{array}{l}\text { - rate of increase } \\
\text { at } 100 \mathrm{C} \\
(\mu / \sqrt{\text { day })}\end{array}$ & 0.63 & 0.16 & 0.19 \\
\hline \multicolumn{4}{|l|}{ Homologous temp. 0.88} \\
\hline $\begin{array}{l}\circ \text { thick. increase } \\
0.88 \mathrm{~T}_{m}, 400 \text { days } \\
\text { (microns) }\end{array}$ & $\begin{array}{l}7.0 \\
(85 \mathrm{C})\end{array}$ & $\begin{array}{l}19.1 \\
\text { (170C) }\end{array}$ & $\begin{array}{l}13.2 \\
(135 \mathrm{C})\end{array}$ \\
\hline $\begin{array}{l}\text { orate of increase } \\
0.88 \mathrm{~T}_{\mathrm{m}} \\
(\mu / \sqrt{\text { day })}\end{array}$ & $\begin{array}{l}0.32 \\
(85 \mathrm{C})\end{array}$ & $\begin{array}{r}0.89 \\
(1700)\end{array}$ & $\begin{array}{l}0.68 \\
(1355 \mathrm{C})\end{array}$ \\
\hline
\end{tabular}

Table 1 Growth Properties of Selected Solders. 